\title{
Bioaccumulation of Arsenic in Aquacultural Large-Scale Mullet Liza macrolepis from Blackfoot Disease Area in Taiwan
}

\author{
M.-C. Lin, ${ }^{1}$ C.-M. Liao, ${ }^{2}$ C.-W. Liu, ${ }^{2}$ S. Singh ${ }^{2}$ \\ 1 Institute of Zoology, Academia Sinica, Taipei 115, Taiwan, Republic of China \\ 2 Department of Agricultural Engineering, National Taiwan University, Taipei 106, \\ Taiwan, Republic of China
}

Received: 17 November 2000/Accepted: 15 April 2001

Arsenic (As) widely distributes in nature and is mainly transported by water in the environment (Ferguson and Gavis, 1972). Arsenic concentrations in the biota of aquatic ecosystems are much higher than those found in the organisms inhabiting terrestrial environments (Lunde, 1977). Naturally-occurring As has been found in many species of aquatic organisms, yet it has not been documented to be an essential element (Uthus et al., 1983) and Phillips (1990) noted that As is toxic to aquatic animals. Arsenic can be accumulated by humans via the dietary route of consuming these animals, such as fish. Fish and shellfish are major contributors to dietary As among seafood consumers. Thus, it is important to know the levels of As in fish and shellfish when estimating risks from seafood consumption. Donohue and Abernathy (1999) reported that the total As in marine fish, shellfish, and freshwater fish tissues ranged from $0.19-65,0.2-125.9$, and $0.007-1.46$ $\mathrm{mg} \mathrm{kg}^{-1}$.

Arsenic is also very toxic to humans (Borum and Abernathy, 1994). The studies of risk assessment concerning chronic exposure to As showed that As has a carcinogenic potential in humans (Thomas, 1994; Buchet, et al., 1996). Chen et al. $(1988,1992)$ and Chiou et al. (1995) pointed out that As levels in water are associated with cancers of skin, lung, liver, bladder, kidney, prostate and colon. In addition, Chen et al. (1980) indicated that high As concentrations in groundwater are related to blackfoot disease (BFD).

BFD is a peripheral vascular disorder found in a limited area on the southwest coast of Taiwan. The BFD area consists mainly of four towns, Putai, Yichu, Peimen and Hsuehchia, located in Chiayi and Tainan counties (Chen et al., 1980). The BFD, first observed in the 1930s and peaking in the $1950 \mathrm{~s}$, correlated with the consumption of groundwater by local inhabitants. Outbreak of the disease increased when the number of deep artesian wells drilled by local villagers for drinking water reached a maximum. The cause of BFD is still unknown, but it generally was attributed to the high concentrations of As found in the groundwater. Nowadays, most of the people living in these areas do not drink water from wells because tap water has been made available; however, the groundwater is still used for aquaculture. 
Farming of large-scale mullet Liza macrolepis is a promising aquaculture in the BFD area in Taiwan because of high market value. Fishermen collect juvenile large-scale mullet from the sea, and keep the fish in ponds. The fish are fed with artificial bait, which does not contain As. These fish are maintained in the ponds for 8 months (from March to October) before they are consumable. Arsenic can be accumulated in fish tissues, therefore the As accumulation in the fish from the ambient water is necessary to be assessed to predict the risk to human health. The process of accumulation of water-borne chemicals by fish and other aquatic animals through nondietary routes is defined as bioconcentration (Connell, 1998). The bioconcentration factor (BCF), relating the concentration of a chemical in water to its concentration in the aquatic animal at steady-state equilibrium, is generally used to estimate the propensity to accumulate chemicals in the organisms (Connell, 1998). Fish are targets for BCF assessments because of their importance as a human food source and the availability of standardized testing protocols (Francesconi et al., 1989; Takatsu and Uchiumi, 1998). Measured or predicted $\mathrm{BCFs}$ are a requisite component for both environmental and human risk assessment (Barron, 1990). In this work, the bioaccumulation of As in Liza macrolepis was studied to assess the potential hazards of As in the aquacultural environment. The As distribution in target tissues of $L$. macrolepis was determined to predict the risk to human health.

\section{MATERIALS AND METHODS}

Water samples were collected from 8 fishponds in the BFD areas every two months for $2 \mathrm{yr}$ (from August 1998 to July 2000). Each time three $500 \mathrm{ml}$ water samples per pond were collected. One-liter polyethylene bottles cleaned with $10 \%$ nitric acid and then rinsed with deionized water were used for the collection of water samples. The water was filtered through a $125 \mu \mathrm{m}$ nylon mesh to remove large suspended particles and macro-invertebrates immediately after collection, and then acidified by adding $5 \mathrm{ml} 1 \mathrm{~N} \mathrm{HNO}_{3}$. Fish samples were collected just before they were sold for consumption. The fish samples were placed in polyethylene bags. All samples were kept at $4^{\circ} \mathrm{C}$ during transfer to the laboratory for As speciation studies. The dissected target tissues of Liza macrolepis were freeze-dried overnight, and then ground to a fine powder in a grinder (Tai-Hsiang S36-89, Taiwan). A $500 \mathrm{mg}$ aliquot of the powders was digested in $10 \mathrm{~mL}$ of $65 \%$ concentrated $\mathrm{HNO}_{3}(\mathrm{v} / \mathrm{v})$ overnight at room temperature. The resulting solution was evaporated and redissolved in $0.1 \mathrm{~N} \mathrm{HCl}$.

A Perkin-Elmer Model 5100PC atomic absorption spectrometer equipped with an HGA-300 graphite furnace atomizer was used to analyze As. Analytical quality control was achieved by digesting and analyzing identical amounts of rehydrated $\left(90 \% \mathrm{H}_{2} \mathrm{O}\right)$ standard reference materials (DORM-2, NRC-CNRC Canada). Recovery rate was $93.5 \pm 3.6 \%$ and the level of detection was $0.0006 \mu \mathrm{g} \mathrm{g}^{-1}$. The curve fitting was performed using the nonlinear regression option of the Statistica $^{(B)}$ software (StatSoft, Tulsa, OK, USA). The coefficient of determination $\left(R^{2}\right)$ and statistical analyses (analysis of variance and Student's $t$ 
test) were also calculated by the Statistica ${ }^{\circledR}$.

\section{RESULTS AND DISCUSSION}

The mean concentrations of As in the culture farms are given in Table 1. Among the 8 culture farms, the average As concentration is $79.9 \pm 60.6 \mu \mathrm{g} \mathrm{L}^{-1}$. There are 4 farms with As concentrations higher than the drinking water standard in Taiwan $\left(50 \mu \mathrm{g} \mathrm{L}^{-1}\right)$, while a recommendation by the World Health Organization is $10 \mu \mathrm{g}$ $\mathrm{L}^{-1}$. The culture farm of Liza macrolepis in Putai (Putai 3), with a measured As concentration as high as $169.7 \pm 68.8 \mu \mathrm{g} \mathrm{L}^{-1}$, has the highest As concentration among all of the sampled culture farms.

Table 1. Mean concentration (Mean $\pm \mathrm{SE}$ ) of As in the water collected from the ponds in BFD area

\begin{tabular}{llc}
\hline Culture farm & Species of aquaculture fish & As concentration in water $\left(\mu \mathrm{g} \mathrm{L}^{-1}\right)$ \\
\hline Putai 1 & Euryhaline teleost $^{\mathrm{a}}$ & $30.6 \pm 5.0$ \\
Putai 2 & Japanese eel $^{\text {b }}$ & $83.4 \pm 48.4$ \\
Putai 3 & Large-scale mullet $^{\mathrm{c}}$ & $169.7 \pm 68.8$ \\
Ichu 1 & Large-scale mullet, Milkfish $^{\mathrm{d}}$ & $36.7 \pm 12.1$ \\
Yichu 2 & Large-scale mullet, Milkfish & $13.0 \pm 6.8$ \\
Peimen 1 & Milkfish & $102.1 \pm 59.0$ \\
Hsuehchia 1 & Euryhaline teleost, Milkfish & $79.2 \pm 18.1$ \\
Hsuehchia 2 & Euryhaline teleost, Milkfish & $47.0 \pm 9.9$ \\
Average & & \\
${ }^{\mathrm{a}}$ Oreochromis mossambicus & \\
${ }^{\mathrm{b}}$ Anguilla japonica & \\
${ }^{\mathrm{c}}$ Liza macrolepis & \\
${ }^{\mathrm{d}}$ Chanos chanos &
\end{tabular}

Eleven Liza macrolepis from the culture farm with the highest As concentration, collected just before they were sold for consumption in late autumn, were analyzed. Analysis of variance (ANOVA) was employed on the results obtained for the fish. Table 2 shows the concentration of As in the tissues of $L$. macrolepis, in which the dorsal muscle, abdominal muscle, gill and liver, contained $2.24 \pm 1.75,2.57 \pm 2.40,2.25 \pm 0.87$ and $2.05 \pm 0.93 \mu \mathrm{g} \mathrm{g}$, respectively. There is no significant difference in concentrations of As accumulation $(F=0.12, n=44, P>0.05)$ among the four tissues (Table 3 ). The average As concentration in the fish body is $2.35 \pm 0.93 \mu \mathrm{g} \mathrm{g}^{-1}$; and the BCF value of As for the fish is determined to be 13.85 . 
Table 2. The concentration of As $\left(\mu \mathrm{g} \mathrm{g}^{-1}\right)$ in the tissues of Liza macrolepis

\begin{tabular}{cccccc}
\hline Fish & Dorsal muscle & Abdominal muscle & Gill & Liver & Average \\
\hline 1 & 0.06 & 1.02 & 1.43 & 4.05 & 1.64 \\
2 & 0.56 & 0.59 & 1.57 & 2.89 & 1.40 \\
3 & 1.08 & 1.11 & 1.28 & 2.83 & 1.58 \\
4 & 1.95 & 1.42 & 1.50 & 0.52 & 1.35 \\
5 & 3.86 & 3.48 & 3.93 & 2.93 & 3.55 \\
6 & 2.38 & 1.63 & 2.76 & 1.97 & 2.19 \\
7 & 3.25 & 0.22 & 3.05 & 2.32 & 2.21 \\
8 & 1.32 & 6.44 & 1.75 & 0.94 & 2.61 \\
9 & 1.28 & 2.92 & 2.65 & 1.23 & 2.02 \\
10 & 2.60 & 1.88 & 1.86 & 2.39 & 2.18 \\
11 & 6.26 & 7.58 & 3.00 & 0.52 & 4.34 \\
Average & 2.24 & 2.57 & 2.25 & 2.05 & 2.35 \\
SE & 1.75 & 2.40 & 0.87 & 1.13 & 0.93 \\
\hline
\end{tabular}

Table 3. The results of the analysis of variance (ANOVA) comparing different tissues, dorsal muscle, abdominal muscle, gill and liver, with As concentrations for Liza macrolepis

\begin{tabular}{lrrrcc}
\hline Source & DF & \multicolumn{1}{c}{ SS } & MS & $F$ & $P$ \\
\hline Between tissues & 3 & 1.17 & 0.39 & 0.12 & 0.8846 \\
Within tissues (error) & 40 & 120.80 & 3.20 & & \\
Total & 43 & 121.97 & & & \\
\hline
\end{tabular}

DF: Degree of freedom

SS: Sum of squares

MS: Mean squares

It is known that the liver is the major organ for detoxification in fish. The reason for the high concentrations of contaminants found in the gill may be that the contaminants are mixed with the mucus of gill lamellae. Wong et al. (1999) showed that contaminant concentrations are lower in muscle as compared to other parts of fish body. In our study, however, the muscle has a similar As accumulation concentration with the liver and the gill.

Significant variations $(F=3.47, n=11, P<0.05)$ between As concentrations and fish individuals of Liza macrolepis were found (Table 4). The As concentration in L. macrolepis showed a significant allometric, negatively correlating with the 


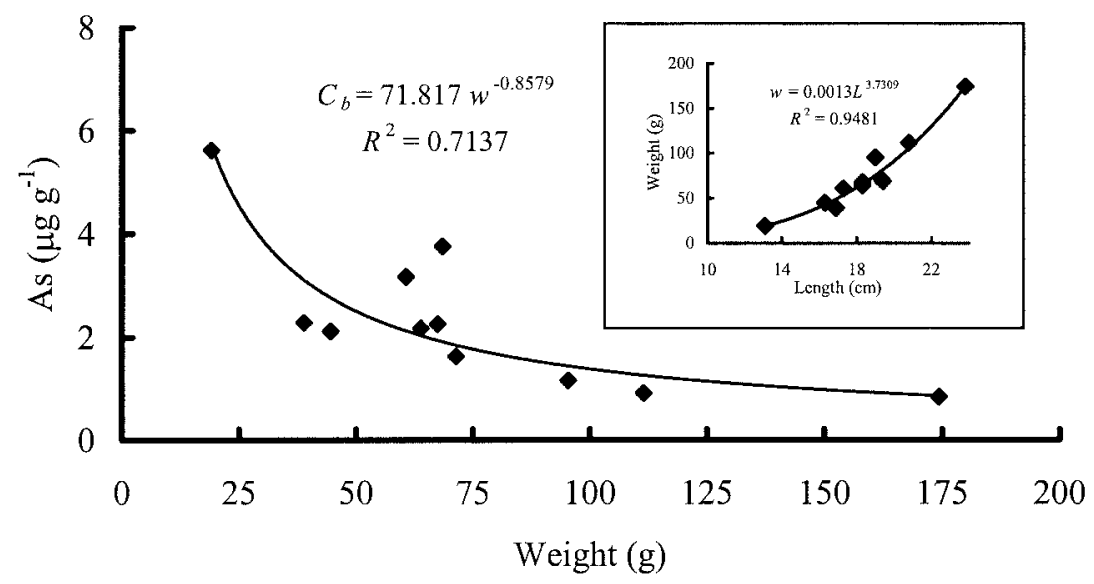

Figure 1. Plots of the correlation between the As concentration and the body weight of Liza macrolepis. The relationship between body weight and length is also shown.

Table 4. The results of the analysis of variance (ANOVA) comparing different fish individuals with As concentrations for Liza macrolepis

\begin{tabular}{lccccc}
\hline Source & DF & SS & MS & $F$ & $P$ \\
\hline Between individuals & 10 & 59.18 & 5.92 & 3.47 & 0.0071 \\
Within individuals (error) & 22 & 37.51 & 1.70 & & \\
Total & 32 & 96.69 & & & \\
\hline
\end{tabular}

DF: Degree of freedom

SS: Sum of squares

MS: Mean squares

body weight of the fish $\left(R^{2}=0.714, n=11, P<0.05\right)$ (Fig. 1). Fig. 1 shows a least-squares nonlinear regression plotted for the As concentration and body weight of the fish as $C_{b}=71.827 w^{-0.8579}$, where $C_{b}$ is the As concentration in fish body $\left(\mu \mathrm{g} \mathrm{g}^{-1}\right)$ and $w$ is the body weight of fish (g). The processes that caused the decrease in the concentrations of As in the larger fish may due to a "growth dilution" effect (Sijm et al., 1992), suggesting that As metabolism in fish plays an important role in As accumulation in fish tissue. Since using the groundwater for aquaculture may cause an overexposure of As. The fish culture industry $L$. macrolepis is vulnerable to the effects of As pollution because As may be toxic to the fish. The consumption of cultured fish from the BFD area may pose a risk to human health. Arsenic concentrations in Liza macrolepis as well as in the other fish need to be evaluated in further research to investigate potential risk to the 
public consuming the As contaminated fish.

Acknowledgments. We thank Dr. Han-Chuan Chiang, Mr. Chien-Hua Chang and Mr. Po-Ching Chen for deploying experimental equipment and providing technical assistance, and Miss Yu-Min Yeh for her help with statistical analysis. This study was supported by the National Science Council of Republic of China under Grant NSC 88-2313-B-002-070.

\section{REFERENCES}

Barron MG (1990) Bioconcentration. Environ Sci Technol 24:1612-1618

Borum DR, Abernathy CO (1994) Human oral exposure to inorganic As. Environ Geochem Health 16:21-29

Buchet JP, Lison D, Ruggeri M., Foa V, Elia G (1996) Assessment of exposure to inorganic As, a human carcinogen, due to the consumption of seafood. Arch Toxicol 70:773-778

Chen CJ., Chen CW, Wu MM, Kuo TT (1992) Cancer potential in liver, lung, bladder, and kidney due to ingested inorganic arsenic in drinking water. British J Cancer 66:888-892

Chen CJ, Wu MM, Kuo TL (1988) Arsenic and cancers. Lancet 1:414-415

Chen CJ, Wu MM, Lee SS, Wang JD, Cheng SH, Wu HY (1980) Atherogenicity and carcinogenicity of high-arsenic well water: multiple risk factors and related malignant neoplasms of blackfoot disease. Arteriosclerosis 8:452-460

Chiou HY, Hsueh YM, Liaw KF, Horng SF, Chiang MH, Pu YS, Lin JSN, Huang $\mathrm{CH}$, Chen, CJ (1995) Incidence of internal cancers and ingested inorganic As: a seven-year follow-up study in Taiwan. Cancer Res 55:1296-1300

Connell DW (1998) Bioaccumulation of chemicals by aquatic organisms. In: Schuurmann G, Marker B (eds) Ecotoxicology: ecological fundamentals, chemical exposure, and biological effects. John Wiley \& Sons, Inc. and Spektrum Akademischer Verlag Co-Publication, p 439-450

Donohue JM, Abernathy CO (1999) Exposure to inorganic arsenic from fish and shellfish. In: Chappell WR, Abernathy CO, Calderon RL (eds) Arsenic exposure and health effects. Elsevier Science Ltd, Oxford, UK, p 89-98

Ferguson JF, Gavis J (1972) A review of the arsenic cycle in natural waters. Water Res. 6:1259-1274

Francesconi, KA, Edmonds JS, Stick RV (1989) Accumulation of arsenic in yelloweye mullet (Aldrichetta forsteri) following oral administration of organoarsenic compounds and arsenate. Sci Total Environ 79:59-67

Lunde G (1977) Occurrence and transformation of arsenic in the marine environment. Environ Health Perspect 19:47-52

Phillips DJH (1990) Arsenic in aquatic organisms: a review, emphasizing chemical speciation. Aquat Toxicol 16:151-186

Sijm DTHM, Selnen W, Opperhulzen A (1992) Life-cycle biomagnification study in fish. Environ Sci Tech 26:2162-2174

Takatsu A, Uchiumi A (1998) Abnormal arsenic accumulation by fish living in a naturally acidified lake. Analyst 123:73-75 
Thomas DJ (1994) Arsenic toxicity in humans: research problems and prospects. Environ Geochem Health 16:107-111

Uthus EO, Cornatzer WE, Nielsen FH (1983) Consequences of arsenic deprivation in laboratory animals. In: Lederer WH, Fensterheim RJ (eds) As: industrial, biomedical, environmental perspectives, Van Nostrand Reinhold, New York, p 173-189

Wong PP, Chu KLM, Wong, CK (1999) Study of toxicity and bioaccumulation of copper in the silver sea bream Sparus sarba. Environ Int 25:417-422 